\title{
Left-handed dental students
}

\section{O estudante de odontologia canhoto}

\section{Abstract}

Objectives: to evaluate the frequency of left-handed students and to investigate their difficulties in Operative \& Restorative Dentistry, first preclinical discipline of the School of Dentistry, University of São Paulo. Materials and methods: 82 students from both genders participated, who were attending the second year of the course, to whom were applied the Edinburgh Handedness Inventory measurements and a questionnaire about the difficulties encountered by lefty students. Results: in the study sample, we found 6 left-handed students (7\%). The greater difficulty reported by them during their laboratorial practice was working in the quadrants on the right side of the manikin's mouth. Conclusion: therefore, it is clear that Dentistry Schools should be aware of this minority, with regard to the material and equipment availability for lefties, as well as recognition of their difficulties and to orient them to obtain the best performance with minimum discomfort.

\section{KEYWORDS}

Dentistry students; functional laterality; teaching.
Maria Aparecida SILVA

$\mathrm{PhD}$ Student - Department of Restorative Dentistry - School of Dentistry - University of São Paulo - São Paulo - SP - Brazil.

Renata Duarte SOUZA-RODRIGUES

PhD Student - Department of Restorative Dentistry - School of Dentistry - University of São Paulo - São Paulo - SP - Brazil.

Karina LASHOWISK

$\mathrm{PhD}$. Student - Department of Restorative Dentistry - School of Dentistry - University of São Paulo - São Paulo - SP - Brazil.

Margarete ODA

Associate Professor - Department of Restorative Dentistry - School of Dentistry - University of São Paulo - São Paulo - SP - Brazil.

Glauco Fioranelli VIEIRA

Associate Professor - Department of Restorative Dentistry - School of Dentistry - University of São Paulo - São Paulo - SP - Brazil.

\section{Resumo}

Objetivos: Avaliar a frequência de alunos canhotos e investigar suas dificuldades em Dentística Operatória Direta, primeira disciplina pré-clínica da Faculdade de Odontologia da Universidade de São Paulo. Materiais e métodos: Participaram 82 estudantes de ambos os sexos que estavam cursando o segundo ano do curso. Foram aplicados Inventário de Lateralidade de Edimburgo e um questionário sobre as dificuldades encontradas pelos estudantes canhotos. Resultados: $\mathrm{Na}$ amostra do estudo foram identificados seis canhotos (7\%). A maior dificuldade relatada por eles, durante a prática laboratorial, foi trabalhar nos quadrantes do lado direito da boca do manequim. Conclusão: As Escolas de Odontologia devem estar cientes desta minoria, em relação ao material e disponibilidade de equipamentos para os canhotos, bem como o reconhecimento das suas dificuldades e orientá-los para obter o melhor desempenho com o mínimo desconforto.

\section{Palavras-chave}

Lateralidade Funcional; Estudantes de Odontologia; Ensino. 


\section{INTRODUCTION}

Laterality is a specific differentiation of the humans which reflects the asymmetric functional organization of central nervous system and expresses body awareness, assuming the completion of activities with greater strength, precision, preference, speed and coordination, which represent key aspects of school learning [1]. The preference for using the right hand (right-handed person) or the left (lefty) is an example of laterality. Typically, $10 \%$ of the population are classified as left-handed with a higher proportion of men than women [2,3]. The lateral asymmetry is related to biological factors, so innate to the individual.

Although handedness is determined by biological aspects, its manifestation is a product of biological and social factors, because child needs, very early, to adapt to the use of objects designed for righties [4]. Despite all the social and technological changes, the contemporary world remains predominantly righthanded and left-handed frequency tends to decrease with age, possibly due to social pressure, adaptation, even though it decreased the tendency to force lefthanded children to write with their right hand, which denotes an attitude of understanding for the biological characteristic and respect [5].

Left-handers are more likely to suffer an unintentional injury, head trauma, car accidents, increased rate of injuries in sports and industry; moreover lefty workers are five times more likely to have an accidental finger amputation than righties [6].

Some professional fields such as dentistry, which require a high degree of manual dexterity as well as mental images to perform a particular clinical procedure, do not grant better performances to lefties, rather, they commonly feel the inconvenience of their condition, according to a study by Henderson et al [7].

The use of high end technology tools and equipment allowed improving the quality of dentistry work with the execution of increasingly complex tasks. However the industrial production system develops products that meet the majority of the population who is righthanded, forcing the lefty to adapt and this can lead to a decrease in performance and increased perception of discomfort when compared to the same task performed by righties [8]. Although, the level of modern technology enables the adaptation of the workplace for both groups of students (lefties and righties) under the same conditions, ensuring equal comfort for them all and avoiding possible psychophysical harm.

With the modernization of tools and dental equipment, ergonomic requirement is necessary for maintaining a healthy posture and consequent optimization of the work. Thus, the application of ergonomic principles to equipment and the work environment is an effective way to ensure safety, health, motivation and satisfaction [8]. These principles should be systematically passed during the course of Dentistry in order to minimize the risk of future injuries as there are difficulties to be overcome for all subjects, but especially for lefties.

In Brazil, there is no unanimity among the courses as learning ergonomics and its associated training. Specifically at the university where this study was conducted, the ergonomics discipline is not part of the curriculum.

Considering there is a difficulty for lefties to adapt themselves to the instruments and furniture designed for righties, the objective of this study was to identify the frequency of left-handers among the students of the preclinical Operative \& Restorative Dentistry discipline and question their difficulties, with the purpose of seeking ways to solve problems that may increase during the course.

\section{Materials and Methods}

This is a cross-sectional study conducted after approval of the Ethics Committee in Research of the School of Dentistry, University of São Paulo (FOUSP).

Participants: The sample of this study was composed of 82 sophomore students from both genders of FOUSP who took the discipline of Operative \& Restorative Dentistry and had worked in a clinical simulation laboratory, where all equipment was designed for right-handed students. There were no exclusion criteria.

Students were informed about the purpose of the study and those who agreed to participate signed an Informed Consent Form.

\section{Methods}

To obtain data of the students, were given two selfadministered questionnaires:

1. Edinburgh Handedness Inventory [9] to determine the hand preference for everyday motor tasks, when it was identified if the student was righthanded, left-handed or ambidextrous.

2. The self-administered and structured questionnaire, consisting of seven questions to know the difficulties faced by left-handed students (Table 1). 


\section{Table 1 - Questionnaire about the DIFFICULTIES FACED BY LEFT-HANDED STUDENTS}

\begin{tabular}{|c|c|c|c|c|}
\hline & & & YES & $\mathrm{NO}$ \\
\hline 1. & \multicolumn{2}{|c|}{$\begin{array}{l}\text { Do you feel discriminated against for } \\
\text { being left-handed in any discipline of } \\
\text { your course? }\end{array}$} & & \\
\hline 2. & \multicolumn{2}{|c|}{$\begin{array}{l}\text { Does your course offer material } \\
\text { suitable for left-handed? }\end{array}$} & & \\
\hline 3. & \multicolumn{2}{|c|}{$\begin{array}{l}\text { Did you know that there is equipment } \\
\text { designed for lefties? }\end{array}$} & & \\
\hline & \multicolumn{2}{|c|}{$\begin{array}{l}\text { Do you believe that you performance } \\
\text { would be better in any discipline if } \\
\text { you were right-handed? }\end{array}$} & & \\
\hline & \multicolumn{2}{|c|}{$\begin{array}{l}\text { Do you receive any guidance on } \\
\text { how to fit yourself when using right- } \\
\text { handed designed equipment? }\end{array}$} & & \\
\hline & \multicolumn{2}{|c|}{$\begin{array}{l}\text { Do you face any difficulties using the } \\
\text { equipment (often built for righties) } \\
\text { just because you are left-handed? }\end{array}$} & & \\
\hline & \multicolumn{2}{|c|}{$\begin{array}{l}\text { In which quadrant of the dental arch } \\
\text { do you feel harder to work? }\end{array}$} & & \\
\hline & & 2 & & \\
\hline & & 4 & & \\
\hline
\end{tabular}

To analyze the data for the two questionnaires was used descriptive quantitative analysis of the frequency $(\mathrm{p}<0,05)$.

\section{Results}

Of the 82 students evaluated, 27 were men $(33 \%)$ and 55 women $(67 \%) .89 \%$ were right-handed and $7 \%$ were left-handed (5 women and 1 man) (chart 1). There was no statistically significant difference between lefties of both genders $(p=0.37)$. As for the difficulties encountered by left-handed students in the undergraduate program of our institution, $83,3 \%$ reported not receiving guidance on the proper use of the dental equipment and the same students believe that their performance would be better if they were right-handed. The frequency of responses to specific questions about the difficulties of lefties was described in chart 2. It is worth noting that specifically in question seven, one hundred percent said they found most difficult to work in the mouth quadrants 1 and 4 .

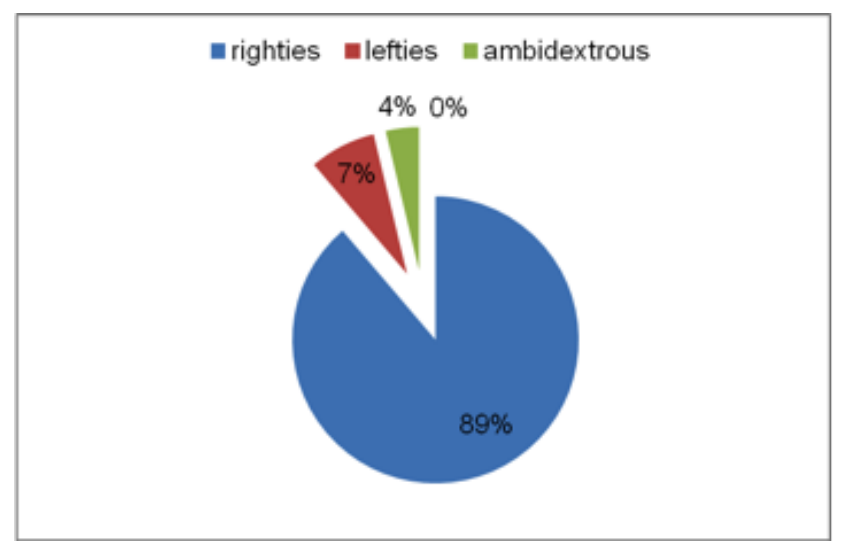

Chart 1 - Handedness Distribution among Students

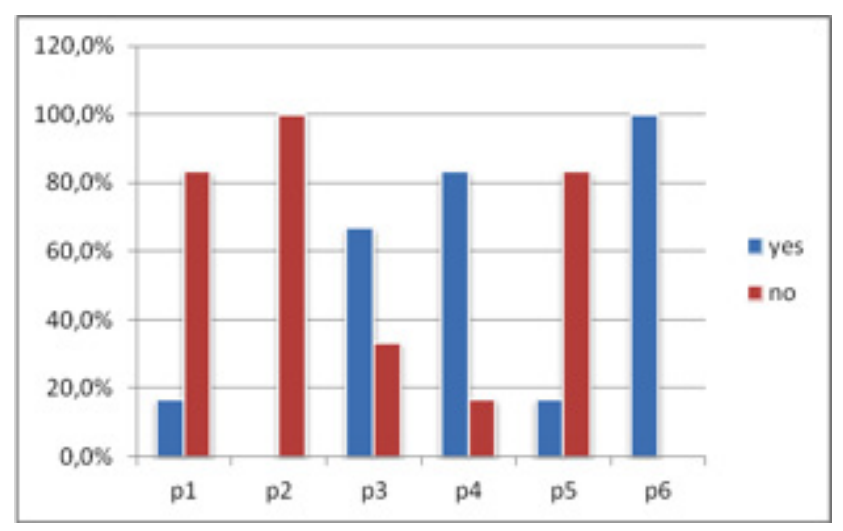

Questions p1 to p6 of the questionnaire on the difficulties faced by lefties students

Chart 2 - Frequency of responses to specific questions about the difficulties of left-handed students

\section{Discussion}

This study aimed to identify the main difficulties of the dental student left-handed. All subjects had just notions of ergonomics and no specific training. These guidelines were given in some clinical disciplines throughout the course, but there was a systematic transmission of theoretical concepts and practical ergonomics. Given this observation, it was found that the difficulty for the lefties is a reality.

This study observed that there was no statistically significant difference between lefties of both genders, contradicting reports of a higher prevalence in males $[10,11]$. However, one must consider that our evaluated study group was small, which may have caused such a difference in results.

As for the difficulties faced by left-handed dentistry students it was found that they do exist, but are still little addressed in our educational institution. The main difficulties reported in the evaluation questionnaire refer to specific guidance regarding the handling 
of equipment and lack of dental chairs specific to them. These results corroborate the findings of other authors [12], who state that although one of the main factors to determine a successful treatment of dental problems is the position adopted by the professional, many dental schools still do not have dental chairs designed specifically for lefties what it could directly affect the dental practice. In their studies with righties and lefties, the same authors found that when working on the left side of the patient, the performance of lefthanded students was significantly better compared to the work done by these students when positioned on the right side of the patient.

In our study, the left-handed students also reported having more difficulty working in the right quadrants of the mouth. However, as students were evaluated in a preclinical course, this complaint may represent only discomfort to position themselves to the right of the manikin, and there is no evidence to infer whether this could pose a real difficulty in treating dental disease in these quadrants as observed by Orbak et al. [7], who observed differences in the diagnosis severity related to the quadrants examined in the assessment of periodontal disease, such as a slight increase in the depth measurement of periodontal pockets located at the right quadrants of the mouth when compared to the left quadrants, a fact that raised the question if that could be related to the handedness of the examiners.

Khan et al [1] reported no influence of the righthanded or left-handed examiner for differences in disease severity in the right or left quadrants, but Canakci et al [13], while observing dental students treating manikins using right sided chairs, verified that lefty students were less successful than their right-sided colleagues in subgingival scaling with curettes, except for facial and mesial surfaces. In terms of successful learning, there was no difference between these groups.

In the subjective evaluation as being left-handed, most felt that their performance would be better if they were right-handed, in line with results found by Henderson [6], and this situation serves as a warning for how those students will be driven, alerting the teacher to reorganize the teaching process, while the college should supply material that fits this group needs. The important thing is to allow this minority to choose its learning process using or not their dominant hand, and only then judge their performance.

The studies about handedness that had contributed to a change in the left-handed child guidance, adjusting the Brazilian educational system, seem not to have reached dental schools, where there are other adjustments to do that go beyond the school desk. As the Brazilian Ministry of Education declared [14]: "The educational system relies its physical support on the school, environment in which is processed the acquisition of knowledge and practices required by cultural and socio-economic demands. This space should provide not only appropriate architectural conditions, but also facilities, equipment and furniture designed in such a way that the students feel well-being receiving, assimilating, reinforcing and applying the knowledge and techniques provided to them.

Ergonomic guidelines established by international bodies like the International Standartization Organization (ISO) as ISO 11.226:2000 (Evaluation of static working postures), ISO 6385:2004 (Ergonomic principles in the design of work systems) and ISO 4073:2009 (Information system on the location of dental equipment in the working area of the oral health care provider) were established with the goal of cataloging ergonomic concepts applied to dentistry and should be followed by all educational institutions so that even in the period of professional training these concepts were part of the routine work, allowing the concern and possible early prevention of musculoskeletal injuries .

During the annual meeting of the European Society of Dental Ergonomics in 2005 was presented a document with guidelines and recommendations for designing, producing and choose dental equipment in order to regulate the exercise of the dentist without prejudice to his health, since the lesions musculoskeletal reach about $65 \%$ of dentists and dental students in San Francisco the pain complaints increased by $70 \%$ in first year students for the third year [15].

Many debates have occurred nowadays about college education, as we live in a process of exhaustion of the traditional superior education model [16], where the teaching needs to be rethought, from associating the eager search for technology appeals by the students, that distances them from real life in the classroom, to clinical practices in which differences need not to be seen as a limiting factor, but rather as recognition of potential difficulties regarding the use of the technique and its best implementation with minimal discomfort.

Early preclinical disciplines play an important role in raising awareness of the students, from the correct handling of the instruments to the positioning in the dental office, where their importance go beyond a precise technique that will result in a good final work. 


\section{Conclusion}

This work showed that do exist some difficulties for left-handed dentistry students caused by the inadequacy of equipment and supplies. Colleges, as well as teachers, should be aware of the existence of this group to better guide and tailor the equipment to their needs, thus promoting a better teaching for these students, for in the end a large investment is allocated in their education.

\section{References}

Recceived: 2013-01-09

Accepted: 2013-03-02

1. Khan MS, Blanchard SB, Dowsett SA, Eckert GJ, Kowolik MJ. Periodontal Assessment by Right- and Left Handed Examiners: Is There a difference? J. Periodontal. 2006; 77(7):1099-103.

2. Gonzalez CLR, Goodale MA. Hand preference for precision grasping predicts language lateralization. Neuropsychologia. 2009; 47(14):3182-9.

3. Alibeik, H. and S.A. Angaji. Developmental Aspects of Lefthandedness. Australian J. Basic and Applied Sci. 2010; 4: 877-81.

4. Grga D, Miletić V. Dental education of Left-handed students. Stom Glas S. 2006; 53: 138-43.

5. Adusumilli PS, Kell C, Chang JH, Tuorto S, Leitman IM. Left-handed surgeons: are they left out? Curr Surg. 2004; 61(6):587-91.

6. Henderson NJ, Stephens CD, Gale D. Left-handedness in dental undergraduates and orthodontic specialists. Br Dent J. 1996; 181(8):285-8.

7. Orbak R, Tezel A, Canakci V, Tan U. Right- and left-handed dentists using right- and left-sided dental chairs in treatment of calculus. Int J Neurosci. 2002; 112(1):15-30.

8. Yarid SD, Diniz DG, Orenha ES, Arcieri RM, Garbin AJI. Aplicação de princípios de ergonomia no atendimento odontológico. Interbio. 2009; 3(2):11-7.

9. Oldfield R.C. The assessment and analysis of handedness: the Edinburg inventory. Neuropychologia. 1971; 9:97-113.

10. Owens JD, Dowsett SA, Eckert GJ, Zero DT, Kowolik MJ. Partial-mouth assessment of periodontal disease in an adult population of the United States. J. Periodontol. 2003; 74:1206-13.

11. Ademola O, Kofoworola O, Omotayo O, Rosemary B, Dolapo D, Edidiong A. The Prevalence of Left-Handedness among Medical and Dental Students in the University of Lagos-Nigeria. Middle-East Journal of Scientific Research. 2011; 8 (1): 288-293.

12. Kaya MD, Orbak R. Performance of left-handed dental students is improved when working from the left side of the patient. International Journal of Industrial Ergonomics. 2004; 33: 387-393.

13. Canakci V, Ciçek Y, Canakci CF, Demir T, Kavrut F, Kara $\mathrm{C}$, et al. Effect of handedness on learning subgingival scaling with curettes: a study on manikins. Int J Neurosci. 2004;114(11):1463-82.

14. BRASIL. Ministério da Educação e Cultura. CE DATE. Mobiliário escolar; carteira universitária. Rio de Janeiro, 1982. 35 p.II (Equipamentos escolares, 2).

15. European Society of Dental Ergonomics. Ergonomic requirements for dental equipment. Guidelines and recommendations for designing, constructing and selecting dental equipment. [cited 2013 Jan 01]. Available from: www. esde.org.

16. Araujo ME. Palavras e silêncio na educação superior em odontologia. Ciência e Saúde Coletiva. 2006;11(1):179-82.

\section{Corresponding Author}

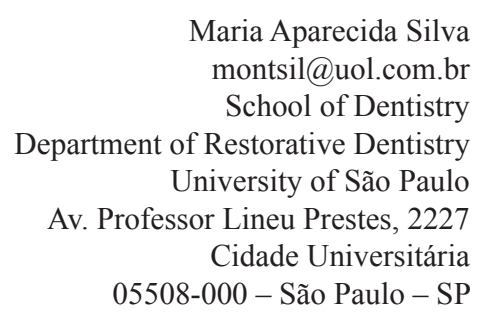

Maria Aparecida Silva montsil@uol.com.br School of Dentistry

University of São Paulo

Cidade Universitária 05508-000 - São Paulo - SP 